\title{
Calcium-independent and steroid-resistant nitric oxide synthase activity in human paranasal sinus mucosa
}

\author{
J.O.N. Lundberg*, E. Weitzberg**, J. Rinder*+, A. Rudehill**, O. Jansson++, \\ N.P. Wiklund + , J.M. Lundberg*, K. Alving*
}

Calcium-independent and steroid-resistant nitric oxide synthase activity in human paranasal sinus mucosa. J.O.N. Lundberg, E. Weitzberg, J. Rinder, A. Rudehill, O. Jansson, N.P. Wiklund, J.M. Lundberg, K. Alving. (C) ERS Journals Ltd 1996.

ABSTRACT: Nitric oxide (NO) is present in the human nasal airways and originates primarily from the paranasal sinuses. Immunohistochemical studies and messenger ribonucleic acid (mRNA) in situ hybridization indicate that a type-2 NO synthase (NOS) is constitutively expressed in healthy sinus epithelium.

We have further characterized sinus NOS activity by studying the enzymatic conversion of $\mathrm{L}$-arginine to $\mathrm{L}$-citrulline in biopsies from sinus mucosa. Maxillary sinus biopsies were obtained from nine healthy subjects during reconstructive facial surgery. In addition, nasal NO concentrations in nine controls were compared with those found in five patients treated with high systemic doses of glucocorticosteroids. Finally, the effects of $i$.v. L-arginine infusion on nasal cavity NO concentrations were studied in six healthy subjects.

$\mathrm{Ca}^{2+-i n d e p e n d e n t ~ N O S ~ a c t i v i t y ~ w a s ~ f o u n d ~ i n ~ a l l ~ b i o p s i e s ~ a n d ~ w a s ~ f i v e ~ t i m e s ~ h i g h e r ~}$ than $\mathrm{Ca}^{2+}$-dependent activity $\left(179 \pm 64\right.$ and $36 \pm 17 \mathrm{pmol}^{-1} \cdot \mathrm{g}^{-1} \mathrm{~min}$, respectively). There was no difference in nasal NO levels between controls $(344 \pm 21$ parts per billion $(\mathrm{ppb}))$ and steroid-treated patients $(342 \pm 36 \mathrm{ppb})$. Nasal NO levels increased up to $35 \%$ following $i$.v. infusion of $\mathrm{L}$-arginine.

We conclude that NOS activity in healthy sinus mucosa is predominantly $\mathrm{Ca}^{2+}$ independent and this NOS is not downregulated by systemic steroids. Furthermore, L-arginine infusion increases nasal airway NO excretion in vivo, indicating that the substrate concentration is a rate-limiting factor under basal conditions. These findings further support the notion that sinus NOS is identical or very closely related to the type-2 NOS; however, the regulation of expression seems to be fundamentally different from that described previously for this NOS isoform.

Eur Respir J., 1996, 9, 1344-1347.
*Dept of Physiology and Pharmacology, Karolinska Institute, Stockholm. Depts of

**Anaesthesiology and Intensive Care, +Oto-Rhino-Laryngology, and ++Urology, Karolinska Hospital, Stockholm, Sweden.

Correspondence: J.O.N. Lundberg Dept of Physiology and Pharmacology Karolinska Institute

17177 Stockholm

Sweden

Keywords: Airways

asthma

exhaled air

nasal cavity

sinusitis

\section{Received: March 291996}

Accepted after revision May 221996

This study was supported by grants from the Swedish Medical Research Council (10162, 10354 and 11199), the Tore Nilsson Foundation for Medical Research, the Åke Wiberg Foundation, the Magnus Bergvall Foundation, the Swedish Heart-Lung Foundation, the Swedish Tobacco Company.
Nitric oxide (NO) is formed in mammalian cells when the amino acid L-arginine, in the presence of molecular oxygen, is catalytically converted to L-citrulline by enzymes known as NO synthases (NOSs). Three different isoforms of NOS have so far been cloned and sequenced [1-3]. Type-1 NOS (neuronal) and type-3 NOS (endothelial) are constitutively expressed in certain tissues, and produce small amounts of NO in response to agonists that increase intracellular $\mathrm{Ca}^{2+}$ concentrations. Thus, these enzymes are known as $\mathrm{Ca}^{2+}$-dependent NOSs. In contrast, the third cloned NOS (type-2 or macrophage NOS) is not usually present in resting cells but may be expressed following induction by a variety of cytokines or by bacterial lipopolysaccharide. Once expressed, this enzyme can produce large amounts of NO over a long period of time in a $\mathrm{Ca}^{2+}$-independent manner [4]. Moreover, the high-rate NO producing type- 2 NOS may increase its activity if extracellular L-arginine concentrations are raised [5].

NO produced by the type-2 NOS is involved in macrophage killing of a variety of pathogens, including bacteria and viruses $[4,6]$. It has also been suggested that
NO plays a role in the pathogenesis of inflammation when produced in excess by a type- 2 NOS. The expression of type-2 NOS is downregulated by anti-inflammatory drugs, such as glucocorticoids [7].

NO is present in exhaled air of humans [8]. Almost all NO found in exhaled air is derived from the upper respiratory tract, especially the nasal airways [9, 10]. Further studies have shown that the paranasal sinuses are the major sources of the NO found in the nasal cavity $[11,12]$. We have suggested a role for NO in sinus host defence [12], since NO concentrations in air aspirated directly from the maxillary sinuses greatly exceed those that are bacteriostatic [13]. Immunohistochemical and messenger ribonucleic acid (mRNA) in situ hybridization studies of sinus mucosa [12] indicate that sinus NOS is identical or very closely related to the type-2 NOS that has been cloned in activated human hepatocytes [2].

We wanted to further characterize sinus NOS activity by the use of an indirect method that measures the conversion of L-arginine to L-citrulline in vitro. This quantitative method can distinguish between $\mathrm{Ca}^{2+}$-dependent and $\mathrm{Ca}^{2+}$-independent NOS activity. Furthermore, we 
wanted to compare nasal concentrations in controls and in patients treated with high doses of systemic glucocorticoids. Finally, we have also studied the effect of $i . v$. L-arginine infusion on nasal cavity NO concentration in healthy subjects in vivo.

\section{Methods}

\section{NOS activity}

Biopsies were obtained from the maxillary sinus mucosa in nine healthy subjects ( 5 males and 4 females; aged 17-36 yrs) undergoing reconstructive facial surgery due to severe bite dysfunction. None of the subjects had a history of nasal or sinus disorders, such as allergy or sinusitis, and they were not taking any medicine at the time of the operation.

NOS activity was measured as the conversion of $\mathrm{L}^{-}$ $\left[\mathrm{U}^{-14} \mathrm{C}\right]$ arginine to $\mathrm{L}-\left[\mathrm{U}^{-14} \mathrm{C}\right]$ citrulline. For the citrulline formation assay, tissues were homogenized in ice-cold homogenization buffer containing: $320 \mathrm{mM}$ sucrose; $0.1 \mathrm{mM}$ ethylenediamine tetra-acetic acid (EDTA); 1 $\mathrm{mM}$ DL-dithiothreitol; $10 \mu \mathrm{g} \cdot \mathrm{mL}^{-1}$ trypsin inhibitor; 10 $\mu \mathrm{g} \cdot \mathrm{mL}^{-1}$ leupeptine; $100 \mu \mathrm{g} \cdot \mathrm{mL}^{-1}$ phenylmethylsulphonyl fluoride; and $2 \mathrm{mg} \cdot \mathrm{L}^{-1}$ aprotinin (adjusted to $\mathrm{pH} 7.0$ at $20^{\circ} \mathrm{C}$ with $1 \mathrm{M} \mathrm{HCl}$ ). The homogenate was centrifuged at $12,000 \times \mathrm{g}$ for $30 \mathrm{~min}$ at $4^{\circ} \mathrm{C}$, and the soluble fraction was used for measurements of NOS activity. The tissue extract $(20 \mu \mathrm{L})$ was added to tubes prewarmed to $37^{\circ} \mathrm{C}$, containing $100 \mu \mathrm{L}$ of buffer. The buffer consisted of: 50 $\mathrm{mM}$ potassium phosphate ( $\mathrm{pH} 7.0) ; 60 \mathrm{mM}$ valine; $5 \mu \mathrm{M}$ tetrahydrobiopterin; $100 \mu \mathrm{M}$ nicotinamide-adenine dinucleotide phosphate reduced form (NADPH); $1 \mathrm{mM} \mathrm{L-}$

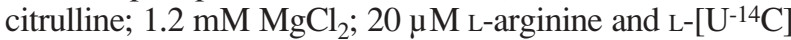
arginine (specific activity $11.7 \mathrm{Gbq} \cdot \mathrm{mmol}^{-1}$, Amersham UK; 150,000 disintegration per minute (dpm)). Duplicate incubations for $10 \mathrm{~min}$ at $37^{\circ} \mathrm{C}$ were performed for each sample in the presence or absence of either EDTA or Nmonomethyl-L-arginine (L-NMMA, $2 \mathrm{mM}$ each), to determine the level of $\mathrm{Ca}^{2+}$-dependent and $\mathrm{Ca}^{2+}$-independent NOS activity, respectively. $\mathrm{Ca}^{2+-i n d e p e n d e n t ~ N O S ~ a c t i-~}$ vity was determined as the difference in activity in the presence of EDTA and background levels (determined as the activity in the presence of both EDTA and LNMMA). The reaction was terminated by removal of the substrate and dilution by the addition of $1.5 \mathrm{~mL}$ of $1: 1$ (v/v) $\mathrm{H}_{2} \mathrm{O} /$ Dowex AF 50W-X8, pH 7.5. Five millilitres of $\mathrm{H}_{2} \mathrm{O}$ was added to the incubation mix, and after sedimentation, $2 \mathrm{~mL}$ of the supernatant was removed and examined for the presence of $\mathrm{L}-\left[\mathrm{U}^{-14} \mathrm{C}\right]$ citrulline by liquid scintillation counting. The amount of citrulline

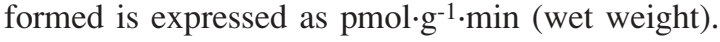

Effects of i.v. L-arginine infusion on NO excretion in nasal airways in vivo

Nasal cavity NO concentrations were measured in six healthy male subjects (aged 31-55 yrs, all co-authors) before and after $i . v$. infusion of L-arginine (2, 20 and 200 $\mathrm{mg} \cdot \mathrm{kg}^{-1} \mathrm{~L}$-arginine hydrochloride $100 \mathrm{mg} \cdot \mathrm{mL}^{-1}$ (L-arginine $\left.80 \mathrm{mg} \cdot \mathrm{mL}^{-1}\right)$, pH 5.5-6; Apoteksbolaget, Umeå, Sweden) using a method described previously [10]. Briefly, an occlusive nasal olive was connected directly to the sampling tube of a chemiluminescence NO analyser (Eco Physics, Dürnten, Switzerland; detection limit 1 part per billion (ppb)) and introduced into one nostril. The subjects held their breath, with the mouth closed, and air was sampled $\left(0.7 \mathrm{~L} \cdot \mathrm{min}^{-1}\right)$ from one nostril until a steadystate was achieved (10-15 s). Heart rate and blood pressure were measured repeatedly before and during the infusion of L-arginine. Ambient NO concentrations were under $4 \mathrm{ppb}$ in all experiments. Calibrations at known concentrations of $\mathrm{NO}$ in $\mathrm{N}_{2}$ (AGA AB; Lidingö, Sweden) were performed using an electromagnetic flow controller (Environics Inc., Middletown, CT, USA).

\section{Effects of steroid treatment on NO excretion in the nasal airways}

Nasal cavity NO concentrations were measured, as described above in nine healthy controls (aged 32-55 yrs; 6 males and 3 females) and in five patients (aged 32-43 yrs; 4 males and 1 female) treated with systemic steroids (betamethasone, Betapred $®$, 4-16 mg daily) due to solid brain tumours of different genesis. None of the patients reported any symptoms from the respiratory tract, such as asthma, allergy or nasal stuffiness. All had been treated with steroids for more than 1 month at the time of the experiment.

\section{Results}

\section{NOS activity}

$\mathrm{Ca}^{2+}$-independent and $\mathrm{Ca}^{2+-}$-dependent NOS activity, as measured by citrulline formation, was found in human maxillary sinus mucosa (fig. 1). Clear-cut $\mathrm{Ca}^{2+}$-independent activity was found in all biopsies, whereas $\mathrm{Ca}^{2+}$ dependent NOS activity was absent $\left(\leq 5 \mathrm{pmol} \cdot \mathrm{g}^{-1} \cdot \mathrm{min}\right)$ in five biopsies.

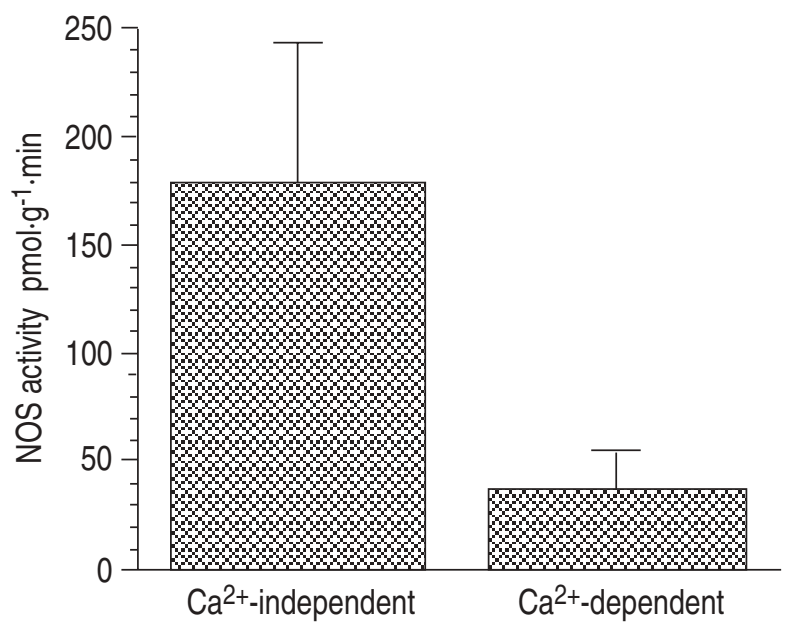

Fig. 1. - $\mathrm{Ca}^{2+}$-dependent and $\mathrm{Ca}^{2+}$-independent nitric oxide synthase (NOS) activity in normal human maxillary mucosa $(n=9)$, as measured by the quantitative conversion of $\mathrm{L}-\left[\mathrm{U}^{-14} \mathrm{C}\right]$ arginine to $\mathrm{L}-\left[\mathrm{U}^{-14} \mathrm{C}\right]$ citrulline. Data are presented as mean \pm SEM. 


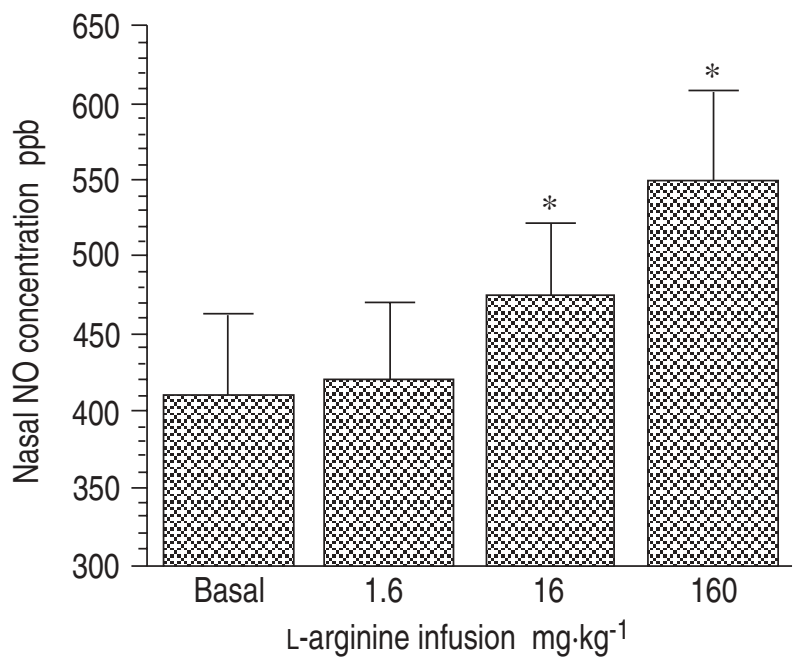

Fig. 2. - Effects of increasing doses of i.v. L-arginine infusion on nasal cavity nitric oxide concentrations in healthy subjects in vivo. Data are presented as mean \pm SEM for six subjects. $*: p<0.05$, compared to basal levels (Wilcoxon's signed rank test). ppb: parts per billion.

Effects of i.v. L-arginine infusion on NO excretion in nasal airways in vivo

Basal nasal NO concentration was $410 \pm 51 \mathrm{ppb}$ and increased dose-dependently following L-arginine infusion, with a $35 \%$ increase at the highest dose (fig. 2). Basal heart rate was $71 \pm 5$ beats $\cdot \mathrm{min}^{-1}$ and did not change following L-arginine infusion. Mean arterial blood pressure also remained unchanged $(85 \pm 3.5 \mathrm{mmHg}$ before and $84 \pm 4 \mathrm{mmHg}$ immediately after infusion of the highest dose of L-arginine).

\section{Effects of steroid treatment on NO excretion in the nasal airways}

Nasal NO concentrations did not differ between controls $(344 \pm 21 \mathrm{ppb})$ and steroid treated patients $(342 \pm 36$ ppb) (fig. 3).

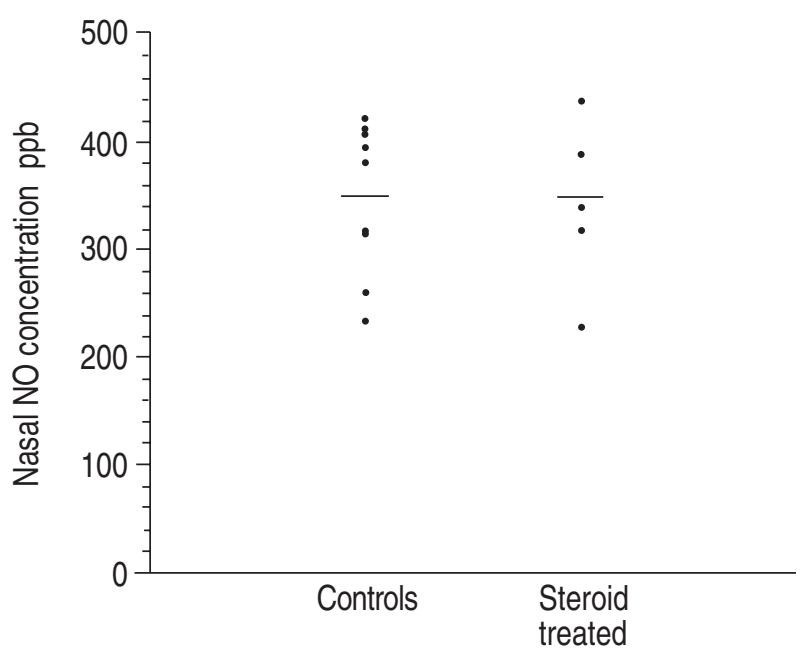

Fig. 3. - NO concentrations in air sampled from the nasal cavity in healthy controls and in patients treated with high doses of systemic glucocorticosteroids. Horizontal bars represent mean. ppb: parts per billion.

\section{Discussion}

This study shows that healthy human maxillary sinus mucosa exhibit NOS activity as measured by the formation of L-citrulline from L-arginine in vitro. This activity is predominantly $\mathrm{Ca}^{2+}$-independent, which is characteristic of the type-2 NOS, also termed inducible NOS (iNOS). The study shows that i.v. L-arginine infusion causes a dose-dependent increase in nasal concentrations of NO without affecting blood pressure, indicating that the highrate NO-producing NOS in the nasal airways functions submaximally due to a relative scarcity of substrate during basal conditions in vivo; whereas, the NOS involved in regulation of blood pressure seems not to be limited by availability of substrate.

These findings, together with earlier immunohistochemical and mRNA in situ hybridization studies on sinus mucosa [12], strongly support the theory that the constitutively expressed enzyme in healthy human paranasal sinus epithelium is a type-2 NOS. In contrast, in the nasal mucosa, only weak NOS activity has been found [12], and this activity was recently shown to be exclusively $\mathrm{Ca}^{2+}$-dependent [14]. The type-2 NOS is normally found, for example, in inflamed tissues or in activated white blood cells [4]. However, there has been considerable debate as to whether this isoform is expressed in healthy tissue. Some authors have reported the expression and activity of iNOS in normal lower airways [15, 16], whilst others have found no iNOS in healthy human bronchi $[17,18]$. This discrepancy is not fully understood. Nevertheless, it is clear that the excretion of NO into the lower airways, as measured in exhaled air, is very low compared to the paranasal sinuses. Thus, NO output in one maxillary sinus may exceed $20 \mathrm{nmol} \cdot \mathrm{min}^{-1}$ [12], whereas total NO excretion in the lower respiratory tract, as measured in orally exhaled air or in air exhaled through a tracheostomy, is less than $5 \mathrm{nmol} \cdot \mathrm{min}^{-1}[10$, 19].

The regulation of sinus NOS expression appears to differ in other ways from that of the type-2 NOS found, for example, in inflamed tissue. Thus, the sinus enzyme does not seem to be downregulated by glucocorticoids even at high doses, as shown in this study. We do not know whether brain tumours might influence basal NO release in the airways, since nasal NO levels were not measured before onset of steroid treatment in the tumour patients. However, it is unlikely that brain tumours of varying genesis would all result in an increase in sinus NO production. Thus, brain tumours are not normally associated with a systemic immune response that might induce NO production. Recent studies indicate that there may be multiple type-2 NOS-like sequences in the human genome [20], which could help to explain these marked differences in regulation of expression.

In view of the present findings, the traditional division of NOSs into inducible and constitutive may not be appropriate, since the type-2 NOS may also be constitutively expressed and active as shown in normal human paranasal sinuses. One might speculate that sinus NOS expression is induced by, for example, luminal bacterial products. However, this seems unlikely since the sinuses are generally considered to be sterile [21]. Furthermore, the mucosa of the nasal cavity, which is normally colonized by bacteria, exhibits markedly less NOS activity [12]. 
The finding that $i . v$. administration of L-arginine increased NO excretion in the nasal airways is interesting, considering the potential involvement of NO in airway host defence [12]. Subjects with Kartagener's syndrome [10] or cystic fibrosis [22] show markedly reduced nasal NO levels, and these patients suffer from recurrent airway infections [22]. One might, therefore, speculate that Larginine supplementation could increase resistance to airborne infectious agents.

The weak $\mathrm{Ca}^{2+}$-dependent NOS activity found in some but not all of the sinus mucosal biopsies may be explained by contribution from type- 1 and type- 3 NOSs in mucosal nerves and endothelial cells of blood vessels.

We conclude that healthy human maxillary sinus mucosa exhibit NO synthase activity that is predominantly $\mathrm{Ca}^{2+}$-independent. Furthermore, $\mathrm{NO}$ excretion in the nasal airways is not supressed by steroids but may be increased in vivo by infusion of $\mathrm{L}$-arginine. These findings further support the notion that sinus NO synthase is identical or very closely related to type- $2 \mathrm{NO}$ synthase. However, there is a fundamental difference in regulation between sinus NO synthase and the type- 2 NO synthase found in inflamed tissue or in activated white blood cells. Thus, sinus NO synthase is constitutively expressed and is not downregulated by steroids.

Acknowledgements: The authors thank C. Nihlén for expert technical assistance.

\section{References}

1. Marsden PA, Heng HHQ, Scherer SW, et al. Structure and chromosomal localisation of the human constitutive endothelial nitric oxide synthase. J Biol Chem 1993; 268: 17478-17488.

2. Geller DA, Lowenstein CJ, Shapiro RA, et al. Molecular cloning and expression of inducible nitric oxide synthase from hepatocytes. Proc Natl Acad Sci USA 1993; 90: 3491-3495.

3. Nakane M, Schmidt HHHW, Pollock JS, Forstermann U, Murad F. Cloned human brain nitric oxide synthase is highly expressed in human skeletal muscle. FEBS Lett 1993; 316: 175-180.

4. Nathan C. Nitric oxide as a secretory product of mammalian cells. FASEB J 1992; 6: 3051-3064.

5. Schott CA, Gray GA, Stocklet JC. Dependence of endotoxin-induced vascular hyporeactivity on extracellular Larginine. Br J Pharmacol 1993; 108: 38-43.

6. Croen KD. Evidence for an antiviral effect of nitric oxide. J Clin Invest 1993; 91: 2446-2452.

7. Nussler AK, Billiar TR. Inflammation, immunoregula- tion, and inducible nitric oxide synthase. J Leuk Biol 1993; 54: 171-178.

8. Gustafsson LE, Leone AM, Persson MG, Wiklund NP, Moncada S. Endogenous nitric oxide is present in the exhaled air of rabbits, guinea-pigs and humans. Biochem Biopys Res Commun 1991; 181: 852-857.

9. Alving K, Weitzberg E, Lundberg JM. Increased amounts of nitric oxide in exhaled air of asthmatics. Eur Respir J 1993; 6: 1368-1370.

10. Lundberg JON, Weitzberg E, Nordvall SL, Kuylenstierna $\mathrm{R}$, Lundberg JM, Alving K. Primarily nasal origin of exhaled nitric oxide and absence in Kartagener's syndrome. Eur Respir J 1994; 7: 1501-1504.

11. Lundberg JON, Rinder J, Weitzberg E, Lundberg JM, Alving K. Nasally exhaled nitric oxide in humans originates mainly in the paranasal sinuses. Acta Physiol Scand 1994; 152: 431-432.

12. Lundberg JON, Farkas-Szallasi T, Weitzberg E, et al. High nitric oxide production in human paranasal sinuses. Nature Med 1995; 1: 370-373.

13. Mancinelli RL, McKay CP. Effects of nitric oxide and nitrogen dioxide on bacterial growth. Appl Environ Microbiol 1983; 46: 198-202.

14. Ramis I, Lorente J, Roselló-Catafau J, Quesada P, Gelpi E, Bulbena O. Differential activity of nitric oxide synthase in human nasal mucosa and polyps. Eur Respir $J$ 1996; 9: 202-206.

15. Guo FH, De Raeve HR, Rice TW, Stuehr DJ, Thunnissen FB, Erzurum SC. Continuous nitric oxide synthesis by inducible nitric oxide synthase in normal airway epithelium in vivo. Proc Natl Acad Sci USA 1995; 92: 7809-7813.

16. Kobzik L, Bredt DS, Lovenstein CJ, et al. Nitric oxide synthase in human and rat lung: immunocytochemical and histochemical localization. Am J Respir Cell Mol Biol 1993; 9: 371-377.

17. Asano K, Chee CBE, Gaston B, et al. Constitutive and inducible nitric oxide synthase gene expression regulation and activity in human lung epithelial cells. Proc Natl Acad Sci USA 1994; 91: 10089-10093.

18. Hamid Q, Springall DR, Riveros-Moreno V, et al. Induction of nitric oxide synthase in asthma. Lancet 1993; 342: 1510-1513.

19. Trolin G, Anden T, Hedenstierna G. Nitric oxide in expired air at rest and during exercise. Acta Physiol Scand 1994; 151: 159-163.

20. Xu W, Charles IG, Liu L, Koni PA, Moncada S, Emson P. Molecular genetic analysis of the duplication of human inducible nitric oxide synthase (NOS-2) sequences. Biochem Biophys Res Commun 1995; 212: 466-472.

21. Stein JH, ed. Internal Medicine. St Louis, Mosby-Year Book, Inc., 1994.

22. Lundberg JON. Airborne nitric oxide: inflammatory marker and aerocrine messenger in man. Acta Physiol Scand 1996; (Suppl. 633): 1-27. 